\title{
Comparison of Two Real-Time PCR Assays for Apolipoprotein E Genotyping
}

Yu Jung Jung, Rihwa Choi, Jae-Young Chung, Myoung-Keun Lee, Chang-Seok Ki, and Jong-Won Kim Department of Laboratory Medicine and Genetics, Samsung Medical Center, Sungkyunkwan University School of Medicine, Seoul, Korea

Corresponding author: Chang-Seok Ki

Department of Laboratory Medicine and Genetics, Samsung Medical Center, Sungkyunkwan University School of Medicine,

81 Irwon-ro, Gangnam-gu, Seoul 135-710, Korea

Tel: +82-2-3410-2709

Fax: +82-2-3410-2719

E-mail: changski@skku.edu

pISSN: $1225-097 \mathrm{X}$

eISSN: 2288-7261
Apolipoprotein E (APOE) polymorphisms are used as biological markers to assess the risk of cardiovascular disease, dyslipidemia, and Alzheimer's disease. Consequently, APOE genotyping is one of the most frequently conducted tests in clinical molecular laboratories. Although $A P O E$ genotyping may appear to be uncomplicated and a relatively easy test to perform, genotyping errors can still occur due to polymorphisms near codons 112 and 158 in the human $A P O E$ gene. Therefore, validation and verification of APOE genotyping assays before clinical use are essential. So far, we have been using the TaqMan SNP Genotyping Assay (Life Technologies, USA). However, recently, the Real-Q ApoE genotyping kit (BioSewoom, Korea) was approved by the Korean Ministry of Food and Drug Safety, which led us to compare the results obtained from this genotyping kit to those of the TaqMan SNP Genotyping Assay. The Real-Q ApoE genotyping kit yielded correct genotyping results for all six APOE genotypes and provided concordant results with the TaqMan SNP Genotyping Assay in a series of blinded comparison samples. Thus, we validated its use in clinical tests.

(J Lab Med Qual Assur 2014;36:157-160)

Key Words : Apolipoprotein E, Genotype, Real-time polymerase chain reaction

Received August 7, 2014, Revision received August 20, 2014, Accepted August 20, 2014
Apolipoprotein E (APOE) polymorphisms are used as biological markers to assess the risk of cardiovascular disease, dyslipidemia, and Alzheimer's disease [1,2]. The human APOE gene, located on chromosome 19q13.2, is polymorphic at codons 112 and 158 , yielding three common codominant alleles $(\varepsilon 2, \varepsilon 3$, and $\varepsilon 4)$ and six different genotypes [2-5]. Although sequencing analysis is currently the standard method for APOE genotyping, it is laborious, expensive, and time-consuming. Hence, several molecular methods, including allele-specific polymerase chain reaction [6,7], PCR-restriction fragment length polymorphism [8], and real-time PCR assays using fluorescence resonance energy transfer or TaqMan probes, have been developed [9-13].

We have used the TaqMan SNP Genotyping Assay (Life Technologies, Grand Island, NY, USA). However, recently, the Real-Q ApoE genotyping kit (BioSewoom, Seoul, Korea) was approved by the Korean Ministry of Food and Drug Safety, leading us to evaluate this genotyping kit and compare its results to those of the TaqMan SNP Genotyping Assay.

Twenty-one specimens with known APOE genotypes (set 1), as determined by the TaqMan SNP Genotyping Assay, and another 53 specimens with unknown APOE 


\section{Journal of LABORATORY MEDICINE and QUALITY ASSURANCE}

\section{Yu Jung Jung et al • Comparison of APOE Genotyping Assays}

genotypes (set 2) were used to compare the two assays. Genomic DNA (gDNA) was extracted from EDTAanticoagulated whole blood using the MagNA Pure LC 2.0 System (Roche Applied Science, Penzberg, Germany), according to the manufacturer's instructions. For the TaqMan SNP Genotyping Assay, $5 \mu \mathrm{L}$ of TaqMan reagent ( $2 \times$ TaqMan GTXpress Master Mix), $0.5 \mu \mathrm{L}$ of $20 \times$ TaqMan SNP Genotyping Assay reagent, and $4 \mu \mathrm{L}$ of sterile water were mixed with $0.5 \mu \mathrm{L}$ of gDNA (100 ng/ $\mu \mathrm{L})$. After a pre-heating step at $95^{\circ} \mathrm{C}$ for 20 seconds, 40 reaction cycles were performed using the Applied Biosystems 7500 Real-Time PCR System platform (Applied Biosystems, Foster City, CA, USA) with a denaturation step at $95^{\circ} \mathrm{C}$ for 3 seconds and annealing and extension at $60^{\circ} \mathrm{C}$ for 30 seconds each. After the procedure, the genotypes were determined using the Sequence Detection System software (Applied Biosystems).

For the Real-Q ApoE genotyping assay, $21 \mu \mathrm{L}$ of master mix (including $17.5 \mu \mathrm{L}$ of reaction mixture, $3 \mu \mathrm{L}$ of a primer mixture for codon 112 and 158 , and $0.5 \mu \mathrm{L}$ of sterile water) was mixed with $4 \mu \mathrm{L}$ of gDNA. A preheating step at $95^{\circ} \mathrm{C}$ for 10 minutes was followed by 40 reaction cycles, which were performed on the Applied Biosystems 7500 Real-Time PCR System platform, was carried out along with a denaturation step at $95^{\circ} \mathrm{C}$ for 20 seconds and annealing and extension at $60^{\circ} \mathrm{C}$ and $72^{\circ} \mathrm{C}$, respectively, for 30 seconds each. When the reaction cycles were completed, the results were analysed by the standard curve method (Applied Biosystems).

Set 1 included all six possible APOE genotypes: $\varepsilon 2 / \varepsilon 2$ $(n=2), \varepsilon 2 / \varepsilon 3(n=7), \varepsilon 2 / \varepsilon 4(n=2), \varepsilon 3 / \varepsilon 3(3), \varepsilon 3 / \varepsilon 4(n=5)$

Table 1. APOE genotyping results of 53 unknown samples

\begin{tabular}{cc}
\hline APOE genotype & No. of samples (\%) \\
\hline$\varepsilon 2 / \varepsilon 2$ & 0 \\
$\varepsilon 2 / \varepsilon 3$ & $4(7.5)$ \\
$\varepsilon 2 / \varepsilon 4$ & 0 \\
$\varepsilon 3 / \varepsilon 3$ & $37(69.8)$ \\
$\varepsilon 3 / \varepsilon 4$ & $12(22.6)$ \\
$\varepsilon 4 / \varepsilon 4$ & 0 \\
\hline
\end{tabular}

Abbreviation: APOE, apolipoprotein E. and $\varepsilon 4 / \varepsilon 4(n=2)$, which were all genotyped correctly using the Real-Q ApoE genotyping assay. Among set 2, the $83 /$ $\varepsilon 3$ genotype ( $n=37)$ was the most common, followed by the $\varepsilon 3 / \varepsilon 4$ genotype $(n=12)$. The results of the two assays were completely concordant in the genotypes of all 53 specimens (Table 1 ).

$A P O E$ genotyping is one of the most frequently conducted tests in clinical molecular laboratories, along with the methylenetetrahydrofolate genotyping test. Recent reports on national proficiency testing by the Korean Institute of Genetic Testing Evaluation showed that 41 institutions are performing APOE genotyping. Among these institutions, Seeplex ApoE ACE Genotyping (Seegene, Seoul, Korea) was most commonly used (in 11 Korean institutions, 26.8\%), followed by the Bio-Core ApoE genotyping PCR KIT (BioCore, Seoul, Korea), which was used by 7 institutions (17.1\%) [14]. Although $A P O E$ genotyping may appear to be uncomplicated and a relatively easy test to perform, genotyping errors can still occur due to polymorphisms near codons 112 and 158 in the human APOE gene [15]. Therefore, validation and verification of $A P O E$ genotyping assays before clinical use are essential.

The Real-Q ApoE genotyping kit yielded correct genotyping results for all APOE genotypes and provided concordant results with the TaqMan SNP Genotyping Assay in a series of blinded comparison samples. Thus, we validated the use of this kit for clinical tests.

\section{REFERENCES}

1. Farrer LA, Cupples LA, Haines JL, Hyman B, Kukull WA, Mayeux R, et al. Effects of age, sex, and ethnicity on the association between apolipoprotein E genotype and Alzheimer disease: a meta-analysis: APOE and Alzheimer Disease Meta Analysis Consortium. JAMA 1997;278: 1349-56.

2. Olaisen B, Teisberg P, Gedde-Dahl T Jr. The locus for apolipoprotein $\mathrm{E}$ (apoE) is linked to the complement component C3 (C3) locus on chromosome 19 in man. Hum Genet 1982;62:233-6.

3. Mahley RW. Apolipoprotein E: cholesterol transport 


\section{Journal of LABORATORY MEDICINE and QUALITY ASSURANCE}

Yu Jung Jung et al $\bullet$ Comparison of APOE Genotyping Assays

protein with expanding role in cell biology. Science 1988; 240:622-30.

4. Paik YK, Chang DJ, Reardon CA, Davies GE, Mahley RW, Taylor JM. Nucleotide sequence and structure of the human apolipoprotein E gene. Proc Natl Acad Sci U S A 1985;82:3445-9.

5. Utermann G, Langenbeck U, Beisiegel U, Weber W. Genetics of the apolipoprotein E system in man. Am J Hum Genet 1980;32:339-47.

6. Donohoe GG, Salomaki A, Lehtimaki T, Pulkki K, Kairisto V. Rapid identification of apolipoprotein E genotypes by multiplex amplification refractory mutation system PCR and capillary gel electrophoresis. Clin Chem 1999;45:143-6.

7. Main BF, Jones PJ, MacGillivray RT, Banfield DK. Apolipoprotein E genotyping using the polymerase chain reaction and allele-specific oligonucleotide primers. J Lipid Res 1991;32:183-7.

8. Mayeux R, Saunders AM, Shea S, Mirra S, Evans D, Roses $\mathrm{AD}$, et al. Utility of the apolipoprotein E genotype in the diagnosis of Alzheimer's disease. Alzheimer's Disease Centers Consortium on Apolipoprotein E and Alzheimer's Disease. N Engl J Med 1998;338:506-11.

9. Aslanidis C, Schmitz G. High-speed apolipoprotein E genotyping and apolipoprotein B3500 mutation detection using real-time fluorescence PCR and melting curves. Clin Chem 1999;45:1094-7.

10. Nauck M, Hoffmann MM, Wieland H, Marz W. Evaluation of the apo E genotyping kit on the LightCycler. Clin Chem 2000;46:722-4.

11. Ballerini S, Bellincampi L, Bernardini S, Casciani S, Motti C, Cortese C, et al. Apolipoprotein E genotyping: a comparative study between restriction endonuclease mapping and allelic discrimination with the LightCycler. Clin Chim Acta 2002;317:71-6.

12. Park HD, Park KU, Kim KW, Song J, Chang HE, Heo $\mathrm{SR}$, et al. Real-time multiplex PCR assay for genotyping of three apolipoprotein E alleles and two choline acetyltransferase alleles with three hybridization probes. Clin Chem Lab Med 2007;45:346-50.

13. Calero O, Hortiguela R, Bullido MJ, Calero M. Apolipoprotein $\mathrm{E}$ genotyping method by real time PCR, a fast and cost-effective alternative to the TaqMan and FRET assays. J Neurosci Methods 2009;183:238-40.

14. Participant Summary Report. Molecular Genetic Tests 2013-2. Korean Institute of Genetic Testing Evaluation.

15. Park CH, Lee ST, Ki CS, Kim JW. Discrepancy in genotyping of apolipoprotein E between allele-specific PCR and fluorescence resonance energy transfer or sequencing. Korean J Lab Med 2010;30:325-8. 


\section{아포지단백 $\mathrm{E}$ 유전자형 검사를 위한 두 가지 실시간 중합효} 소연쇄반응법 비교

\section{정유정・최리화・정재영・이명근 • 기창석• 김종원}

성균관대학교 의과대학 삼성서울병원 진단검사의학과

아포지단백 $\mathrm{E}$ 유전자(apolipoprotein $\mathrm{E}, \mathrm{APOE}$ ) 유전자형 검사는 분자유전검사실에서 가장 흔히 시 행하고 있는 유전자형 검사인데, $A P O E$ 유전자 다형성이 심혈관계질환, 이상지질혈증 및 알츠하이 머 치매의 위험도를 평가하는 생물학적 지표로 활용되고 있기 때문이다. APOE 유전자형 검사는 비 교적 시행이 간편한 검사이지만, $A P O E$ 유전자 다형성을 결정하는 112번째 및 158번째 아미노산 주 변의 또 다른 다형성으로 인해 유전자형 판별 오류가 일어날 가능성이 있다. 따라서 실제 $A P O E$ 유전 자형 검사를 위한 시약을 결정할 때 검증과정이 반드시 필요하다. 본 연구에서는 APOE 유전자형 결 과를 알고 있는 21 개의 검체와 결과를 알지 못하는 53 개의 검체를 이용하여, 기존에 사용하고 있던 TaqMan SNP Genotyping Assay (Life Technologies, USA)와 최근 식품의약품안전처로부터 의 료기기 승인을 받은 Real-Q ApoE genotyping kit (BioSewoom, Korea)를 비교 검증하고자 하였 다. 그 결과 Real-Q ApoE genotyping kit는 결과를 알고 있던 21개의 검체 및 결과를 알지 못했던 53 개의 검체 모두에서 기존 검사법과 일치하는 결과를 보여 임상적으로 사용하기에 적합한 검사법으 로 판단하였다.

(J Lab Med Qual Assur 2014;36:157-160) 